\title{
Comparison of the chemical and amino acid compositions of breast meat of broiler and laying hens
}

\author{
SeungWha Jo', EunJung Yim ${ }^{1}$, Young-Soo Kim ${ }^{2}$, ChangSik $\mathrm{Lo}^{3}$, DongHwa $\mathrm{Shin}^{3 *}$ \\ ${ }^{1}$ Microbial Institute for Fermentation Industry (MIFI), Sunchang 56048, Korea \\ ${ }^{2}$ Department of Food Science and Technology, Jeonbuk National University, Jeonju 54896, Korea \\ ${ }^{3}$ Shindonghwa Food Rearch Institute, Seoul 06192, Korea
}

\section{육계 및 산란계 닭가슴살의 일반성분과 아미노산 조성 비교}

\author{
조승화 ${ }^{1} \cdot$ 임은정 $^{1} \cdot$ 김영수 $^{2} \cdot$ 노창식 $^{3} \cdot$ 신동화 $^{3 *}$ \\ ${ }^{1}$ (재)발효미생물산업진흥원, ${ }^{2}$ 전북대학교 식품공학과, ${ }^{3}$ 신동화식품연구소
}

\begin{abstract}
This study aimed to compare the chemical and amino acid compositions of the breast meat of broiler and laying hens, which have low acceptance in the market. The breast meats were analyzed for the chemical and amino acid compositions of hydrolysates digested by protease at optimum reaction conditions using the amino acid analyzer. No significant differences in moisture and ash contents were detected between the two types of breast meat. However, there were significant differences in the crude lipid and protein contents of laying hen $(1.01 \%$ and $23.68 \%$, respectively) and broiler hen (1.54\% and $25.41 \%$, respectively) meat samples. The amino acid contents of the breast meat samples of the laying and broiler hens were as follows: aspartic acid $(6.88 \%$ and $9.84 \%$, respectively), leucine $(2.01 \%$ and $2.99 \%$, respectively), and arginine $(0.97 \%$ and $1.32 \%$, respectively). Furthermore, the broiler meat had higher contents of essential amino acids such as valine, methionine, isoleucine, leucine, and phenylalanine. The total essential amino acid contents of the two types of meat were $5.87 \%$ (laying) and $8.29 \%$ (broiler), while the branched chain amino acid contents were $2.97 \%$ (laying) and $4.60 \%$ (broiler). The result of this study suggests that the hydrolysate of broiler breast meat could possibly be utilized as functional ingredient for patient foods, elderly food, sports drink and condiment sources.
\end{abstract}

Key words : chicken, breast, amino acid, essential amino acid, branched chain amino acid

서 론

단백질은 3 대 영양소 중 하나로 아미노산을 기본단위로 구 성된 고분자 물질로 근육을 형성하는 중요 성분이고 면역체를 만드는 데 필수성분으로 육류, 달걀과 두류, 견과류에 많이 함 유되어 있다(Patel, 2020). 단백질은 인체에 필요한 양을 매일 식품을 통하여 공급하지 못하면 심각한 영양불균형으로 건강
유지가 어렵고, 성장에 지장을 주며 일병방어기능이 약화된 다. 한국인에게 일일 공급되는 단백질량은 $88.1 \mathrm{~g}$ 이나, 이 기 준량을 공급받지 못하는 인구 비율은 $19.4 \%$ 에 이른다는 보 고이다(KDCA, Korea 2019). 미국의 경우도 성인의 경우(남 자 기준) 일일 $56 \mathrm{~g}$ 을 권장하고 있다(USDA, 2015).

우리나라 육류 소비량은 2018년 기준 돼지고기 $27.0 \mathrm{~kg}$, 닭 고기 $14.2 \mathrm{~kg}$, 쇠고기가 $12.7 \mathrm{~kg}$ 으로 이중 닭고기는 전체 육류

*Corresponding author. E-mail : dhshin@jbnu.ac.kr, Phone :+82-2-539-9361, Fax :+82-2-539-9361

Received 04 January 2021; Revised 27 January 2021; Accepted 29 January 2021.

Copyright (c) The Korean Society of Food Preservation.

This is an Open Access article distributed under the terms of the Creative Commons Attribution Non-Commercial License (http://creativecommons.org/licenses/by-nc/4.0) which permits unrestricted non-commercial use, distribution, and reproduction in any medium, provided the original work is properly cited. 
의 $26.3 \%$ 를 차지하고 있어 중요한 육류자원이다(MAFRA, 2018).

닭고기의 단백질은 가슴살 등 백색육에 많이 함유되어 있 고, 지방과 콜레스테롤은 소고기 등 적색육에 집중되어 있으 며, 백색육의 지방은 적색육의 지방보다 포화도가 높다 (Postati, 1979). 닭의 살코기와 비교할 때 닭고기의 껍질은 지방, 콜레스테롤, 단순 포화지방산을 더 많이 함유하고 있 다. 닭고기는 $20 \%$ 내외가 단백질이며, 육계의 사육기간이 길 어짐에 따라 지방과 나트륨의 함량이 증가한다고 하였으며 (Simpson과 Goodwin, 1979; Singh와 Essary, 1971; Twining 등, 1978), 4-7주령 육계의 단백질 함량이 증가한다고 했으나 (Twining 등, 1978b), 4-8주령 육계의 단백질 함량 차이는 없 었다고 보고하였다(Goodwin과 Simpson, 1973). 닭가슴살은 단백질 함량이 $23.3 \%$ 이며, 지방은 $0.4 \%$ 에 불과하여 단백질 원으로 우수하다(RRDI, 2017).

닭고기는 영양학적으로 우수하고 다른 고기들에 비해 부 드럽고 특유의 풍미가 있어 모든 연령층에서 선호하며 조리 가공 형태도 다양하여 최근 젊은이들에게 선호되고 있다 (Ahn과 Park, 2002). 특히 닭튀김이 치맥 등의 패스트푸드 형 태로 소비량이 심하게 증가하고 있으며, 건강한 식문화를 추 구하는 현대인의 웰빙 생활에 힘입어 닭고기의 소비는 점진 적으로 증가하고 있다(Kim 등, 2007). 가금류 가공기술의 발 달과 1 인 가족 및 맞벌이 부부 등의 증가로 인하여 통닭보다 는 닭다리 등 부분육에 대한 수요가 급격히 증가하고 있다 (Chae 등, 2012).

닭고기의 부위 중 닭가슴살은 단백질과 지방의 함량이 각 각 약 $23 \%, 1.2 \%(\mathrm{Kim}, 2011)$ 로 다른 부위에 비해 단백질 함 량은 현저히 많고 담백하며, 지방함량은 낮으며 콜레스테롤 은 다른 부위에 비해 절반 수준의 함량을 나타낸다(Koh와 $\mathrm{Yu}, 2015)$. 따라서 닭가슴살은 맛이 담백하며 칼로리 섭취를 줄이는 균형 잡힌 영양식 및 다이어트 식단으로 각광을 받고 있어, 다양한 제품들이 출시되고 있다(Jung 등, 2013).

그러나 닭가슴살은 영양학적으로는 우수하지만, 조직감이 푸석하고 씹힘 감이 좋지 않아 소비자의 기호가 떨어지고 소 비량이 제한되어 닭 가공업체에서는 새로운 용도를 찾아야 할 필요성이 있다(Kong 등, 2008; Schilling 등, 2003; Thielke 등, 2005). 닭가슴살을 숙성, 염지하면 품질 개선이 가능하며 (Warkup, 1993), 특히 숙성은 연도에 중요한 역할을 하는 것 으로 보고되어 있다(Lee 등, 2008).

한편, 유럽에서처럼 요리하는 메뉴나 개인의 기호에 따라 다양한 품종의 닭이 사육되고 있는데, 우리나라의 경우 닭 품 종은 매우 제한적이다. 대부분이 일반 육계로 칭하는 브로일 러(broiler) 품종과 종계로 칭하는 native 품종이 있는데, 이들 의 영양성분 및 특성은 차이가 있다(Nam 등, 2019).
본 연구에서는 국내에서 소비처가 한정된 닭가슴살의 용 도를 확대하기 위하여 종계와 육계의 닭가슴살의 일반성분을 비교하고 단백질 분해효소로 가수분해한 후 아미노산 구성을 확인하여 분해액을 건강 기능성식품의 아미노산 보완 및 조 미원료로 사용할 가능성을 확인하고자 하였다.

\section{재료 및 방법}

\section{실험재료}

본 실험에 사용한 종계는 Indian River 품종으로 충북 음성 에서 56주 사육하여, 2020년 7월 도살한 것으로 털과 내장, 머리를 제거한 것으로 한 마리 당 무게가 $1.6 \mathrm{~kg}$ 내외였고, 육계는 Ross 품종으로 전남 영광에서 30-32일 사육 후 2020 년 8월 도계한 후 종계와 같이 처리하였고, 한 마리 당 무게 는 $1 \mathrm{~kg}$ 내외였다.

\section{일반성분 분석}

각 닭가슴살의 수분, 조단백질, 조지방, 회분 등 일반성분 은 식품공전 식품기준 및 규격의 방법에 따라 (사)KOTITI시 험연구원에 의뢰하여 분석하였다.

\section{닭고기 단백질 분해효소 처리}

예비실험을 통하여 최적 효소 처리조건을 확인한 후, 닭가 슴살을 마쇄기로 곱게 마쇄 후 단백질 분해효소인 alkalase (Novo Nordisk Inc. Bagsvaerd, Denmark)와 flavourzyme (Novo Nordisk)을 첨가하여 $55^{\circ} \mathrm{C}$ 에서 2시간 처리하였다. 처 리액을 여과하여 여액을 2 차에 걸쳐 진공건조한 후 분쇄하여 아미노산 분석 시료로 사용하였다.

\section{아미노산 분석}

아미노산 전처리는 시료 $10 \mathrm{~g}$ 을 취하여 3차 증류수 $30 \mathrm{~mL}$ 를 넣고 교반한 후 $50 \mathrm{~mL}$ 로 정용하였다. 초음파를 이용하여 20 분간 추출한 후 원심분리 $(3,000 \mathrm{rpm}, 10$ 분, J-26 XPI, Beckman, Indianapolis, USA)하였다. 상징액 $2 \mathrm{~mL}$ 에 $5 \%$ TCA $2 \mathrm{~mL}$ 를 넣고 원심분리(10,000 rpm, 10분, J-26 XPI, Beckman)하여 $0.02 \mathrm{~N} \mathrm{HCl}$ 로 희석한 상등액을 $0.2 \mu \mathrm{m}$ membrane filter(Syringe filter, Advatec, Tokyo, Japan)에 통 과시킨 후 amino acid analysis(L-8900, Hitachi Hightechnologies Co., Tokyo, Japan), UV/Vis detector(440-570 $\mathrm{nm}$ ), column(Hitachi $4.6 \times 60 \mathrm{~mm}$ separation, Hitachi $4.6 \times 40$ $\mathrm{mm}$ ammonia filtering, Hitachi high-technologies Co.)를 사용 하여 분석하였다. 시료 주입량은 $20 \mu \mathrm{L}$, 이동상은 buffer set(PH-SET, Kanto, Tokyo, Japan), 분석 온도는 $50^{\circ} \mathrm{C}$, buffer 유속은 $0.40 \mathrm{~mL} / \mathrm{min}$, ninhydrin 유속은 $0.35 \mathrm{~mL} / \mathrm{min}$ 으로 분 
석하였다.

\section{통계 분석}

모든 실험은 3회 이상 반복하여 결과를 도출했으며, 통계프 로그램(SPSS ver. 19.0, IBM Inc., Chicago, IL, USA)을 이용 하여 평균 \pm 표준편차 $(\operatorname{mean} \pm \mathrm{SD})$ 를 계산하였으며, 각 시험 군 간의 통계적 유의성 검정은 Levene's t-test로 검증하였다.

\section{결과 및 고찰}

\section{일반성분}

종계 및 육계 가슴살의 일반성분을 분석한 결과는 Table 1 과 같다. 수분 함량은 종계와 육계에서 $74 \%$ 로 내외로 큰 차 이는 보이지 않았고, 조지방과 조단백질, 회분 함량은 육계가 종계보다 높았다. Goodwin과 Simpson(1973), Scott(1956), Twining(1978)에 따르면 닭고기의 지방은 사육 기간이 길어 지면 지방의 함량이 증가한다고 하였는데 본 연구결과 종계 가 $1.01 \%$ 이고, 육계가 $1.54 \%$ 로 사육기간에 따른 차이는 보 이지 않았다. 이는 이용된 종계 및 육계의 품종, 사료 차이에 의한 것이라고 판단되었다(Goodwin과 Simpson, 1973; Scott, 1956; Twining, 1978). 조단백질 함량은 종계(23.68\%)에 비 해 육계(25.41\%)가 더 높은 함량을 나타내었다. 다른 연구 결 과에 의하면 닭가슴살의 단백질함량은 $23.3 \%$ 였으며(RRDI, 2017), Koh와 $\mathrm{Yu}(2015)$ 에 따르면 닭고기 부위별 단백질 함 량이 가슴살은 $22.9 \%$ 로 본 연구 결과의 값과 유사함을 보여 주었다(Koh와 $\mathrm{Yu}, 2015)$. 회분함량은 종계는 $1.15 \%$, 육계는 $1.26 \%$ 였다.

\section{아미노산 함량}

닭가슴살을 가수분해한 분해액의 아미노산 함량은 Table 2 와 같다. 닭가슴살 가수 분해물 중 아미노산은 총 28 종이 검출 되었으며, 종계와 육계의 aspartic acid는 6.88 과 $9.84 \%$ 의 비 율로 가장 높은 함량을 나타내었고, 그 다음은 leucine(2.01, $2.99 \%)$, arginine $(0.97,1.32 \%)$ 의 순이었다.

총 아미노산 함량은 종계의 경우 $19.37 \%$, 육계는 $27.34 \%$ 로 육계가 높았으며, 필수 아미노산 9종의 함량을 보면 종계 는 $5.87 \%$, 육계는 $8.29 \%$ 로 육계에서 필수아미노산량도 크게
차이가 나는 결과를 보였다. 소고기 등심의 경우, 필수 아미 노산은 $8.66 \%(\mathrm{RDA}, 2016)$ 로 육계와 비슷하였고, 쌀(멥쌀, 일품)의 경우 필수 아미노산의 양은 $1.80 \%$ 였으며, 분지아미 노산은 $0.96 \%(\mathrm{RDA}, 2011)$ 로 닭고기 가슴살보다는 크게 낮 았으며, 제한아미노산인 lysine은 $0.10 \%$ 에 불과하였다.

본 연구에서 leucine은 필수아미노산 중 가장 높은 함량을 나타내었으며, 특히 종계에 비해 육계를 이용한 추출물 소재 에서 가장 높은 함량( $2.99 \%)$ 을 나타내었다. Leucine은 단백 질 합성을 촉진시키고, 세포 내 단백질 분해를 억제하며, 노 화의 지연효과가 있는 라파마이신의 포유류의 표적을 활성화 한다고 알려져 있다(Tymoczko 등, 2010). 또한 인슐린 분비 를 촉진하여 혈중 포도당을 낮추어 혈당조절을 쉽게 하는 특 징을 가지고 있다(Kalogeropoulou 등, 2008).

Histidine과 arginine은 leucine 뒤를 이어 높은 함량을 나 타낸 필수아미노산으로 이 역시 종계에 비해 육계가 더 높은 함량을 나타내었다. Histidine은 항산화 및 항염증 기능을 하며, 내피 세포의 염증을 억제하고(Hasegawa 등, 2012), arginine은 산화질소의 전구체로 사용되어 혈관 확장을 조절하는 데 사 용되는 것으로 알려져 있다( $\mathrm{Wu}$ 등, 1988).

비필수 아미노산인 glutamic aicd는 aspartic acid와 더불어 식품의 미각 특성에서 감칠맛 성분으로 천연 조미료 역할을 하며, 해독작용, 뇌 진정 효과 및 당과 지질대사에 관여하는 성분으로 알려져 있으며(Hong 등, 1989; Kwon 등, 1987), alanine은 해당작용, 당 신생 작용, 구연산 회로에 관여하는 데(Felig, 1973) 이 두 가지가 aspartic acid에 이어 높은 함량 을 나타내었다. 이 두 가지 아미노산 역시 종계에 비해 육계 를 이용한 소재에서 높은 함량을 나타내었다.

한편, 근육형성에 관계가 깊고(Foure와 Bendahan, 2017) 손상근육을 보강하는 데 관여하며(Rahimi 등, 2017), 염증 완 화에 효과가 있는(Bae 등, 2019) leucine, isoleucine, valine 등 분지아미노산(branched amino acid, BACC)은 운동선수의 근육 보강이나, 근육이 약화되어 병세의 회복이 늦어지는 환 자에게 꼭 필요한 아미노산으로 알려졌다. 운동선수용 식품이 나 환자식 배합으로 주요 구성성분인 $\mathrm{BACC}$ 는 종계에 $2.97 \%$, 육계에는 $4.60 \%$ 가 함유되어 월등히 높은 경향으로 새로운 용 도로의 가능성을 보여주고 있다. 한편, 소고기에는 $3.57 \%$ 로 육계보다 낮고, 쌀에는 $0.96 \%$ 로 크게 낮았다. Temesgen 등

Table 1. Chemical composition of chicken breast meats

(unit: $\mathrm{g} / 100 \mathrm{~g}$ )

\begin{tabular}{cllll}
\hline Contribution & Moisture & Crude fat & Crude protein & Ash \\
\hline Laying hen & $74.90 \pm 0.701^{1)}$ & $1.01 \pm 0.20$ & $23.68 \pm 0.26$ & $1.15 \pm 0.09$ \\
Broiler & $74.43 \pm 0.81$ & $1.54 \pm 0.03^{* 2}$ & $25.41 \pm 0.74^{*}$ & $1.26 \pm 0.01$ \\
\hline
\end{tabular}

\footnotetext{
${ }^{1)}$ All values are mean $\pm \mathrm{SD}(\mathrm{n}=3)$.

${ }^{2)}$ Significant differences were compared with the same column at ${ }^{*} \mathrm{p}<0.05$ by Levene's t-test.
} 
Table 2. The content of amino acid in chicken breast hydrolysate (unit: \%)

\begin{tabular}{|c|c|c|}
\hline Amino acids & $\begin{array}{l}\text { Breast of } \\
\text { laying hen }\end{array}$ & $\begin{array}{c}\text { Breast of } \\
\text { broiler }\end{array}$ \\
\hline Phosphoserine & $0.17 \pm 0.04^{1)}$ & $0.19 \pm 0.02$ \\
\hline Taurine & $0.04 \pm 0.03$ & $0.07 \pm 0.03$ \\
\hline Aspartic acid & $6.88 \pm 0.35$ & $9.84 \pm 0.63^{* * 2)}$ \\
\hline Threonine & $0.31 \pm 0.21$ & $0.55 \pm 0.12$ \\
\hline Serine & $0.24 \pm 0.03$ & $0.41 \pm 0.07^{*}$ \\
\hline Glutamic acid & $1.05 \pm 0.03$ & $1.41 \pm 0.29$ \\
\hline Sarcosine & $0.04 \pm 0.01$ & $0.03 \pm 0.02$ \\
\hline$\alpha$-Aminoadipic acid & $0.16 \pm 0.04$ & $0.22 \pm 0.14$ \\
\hline Glycine & $0.07 \pm 0.02$ & $0.30 \pm 0.13^{*}$ \\
\hline Alanine & $0.55 \pm 0.09$ & $1.48 \pm 0.18^{* *}$ \\
\hline$\alpha$-Aminobutyric acid & $0.22 \pm 0.06$ & $0.04 \pm 0.02^{*}$ \\
\hline Valine & $0.57 \pm 0.09$ & $0.93 \pm 0.15^{*}$ \\
\hline Methionine & $0.67 \pm 0.11$ & $1.07 \pm 0.04^{* *}$ \\
\hline Isoleucine & $0.29 \pm 0.04$ & $0.68 \pm 0.11^{* *}$ \\
\hline Leucine & $2.01 \pm 0.22$ & $2.99 \pm 0.32^{*}$ \\
\hline Tyrosine & $0.28 \pm 0.13$ & $0.68 \pm 0.13^{*}$ \\
\hline Phenylalanine & $0.63 \pm 0.14$ & $0.97 \pm 0.10^{*}$ \\
\hline$\beta$-Alanine & $0.71 \pm 0.19$ & $0.62 \pm 0.15$ \\
\hline$\beta$-Aminoisobutyric acid & $0.98 \pm 0.19$ & $1.10 \pm 0.22$ \\
\hline$\gamma$-Aminobutyric acid & $0.12 \pm 0.08$ & $0.10 \pm 0.00$ \\
\hline Tryptophan & $0.21 \pm 0.18$ & $0.27 \pm 0.05$ \\
\hline Ammonia & $0.07 \pm 0.03$ & $0.09 \pm 0.10$ \\
\hline Ornithin & $0.14 \pm 0.02$ & $0.14 \pm 0.06$ \\
\hline Histidine & $0.91 \pm 0.08$ & $1.48 \pm 0.18^{*}$ \\
\hline Lysine & $0.17 \pm 0.13$ & $0.22 \pm 0.09$ \\
\hline 3-Methylhistidine & $0.02 \pm 0.01$ & $0.02 \pm 0.02$ \\
\hline Carnosine & $0.91 \pm 0.08$ & $0.15 \pm 0.15^{* *}$ \\
\hline Arginine & $0.97 \pm 0.23$ & $1.32 \pm 0.23$ \\
\hline Total essential amino acids & $5.87 \pm 0.15$ & $8.29 \pm 0.92^{*}$ \\
\hline Total branched chain amino acids & $2.97 \pm 0.08$ & $4.60 \pm 0.63^{*}$ \\
\hline Total amino acids & $19.37 \pm 1.15$ & $27.34 \pm 0.63^{* *}$ \\
\hline
\end{tabular}

${ }^{1)}$ All values are mean \pm SD $(n=3)$.

${ }^{2)}$ Significant differences were compared with the same row at ${ }^{*} \mathrm{p}<0.05$, ${ }^{*}<0.01$ and by Levene's t-test.
(2018)에 따르면, 사료 배급량 및 종류에 따라서 닭고기의 아 미노산과 지방산 조성이 달라진다고 보고되어 있는데, 앞으 로 닭고기의 아미노산 구성을 개선하기 위해서는 사료에 관 한 연구도 진행되어야 할 것으로 판단된다(Temesgen 등, 2018).

이 연구 결과에서 보듯 종계와 육계의 가슴살은 아미노산 의 구성과 함량에 차이가 있는 것으로 확인되었다. 이는 Chen(2016), Watanabe(2004), Zhao(2011)의 연구와 유사한 결과로, 사육기간 및 도축 연령에 따른 차이에 의해 아미노산 함량 및 근섬유조직, 펩타이드에서 차이를 보여주었다(Chen 등, 2016; Watanabe 등, 2004; Zhao 등, 2011).

\section{요 약}

본 연구에서는 국내 닭고기 중 종계와 육계의 일반성분을 확인하고 가슴살 부위를 단백질 분해효소로 처리하여 아미노 산 조성을 확인하였다. 용도가 제한된 닭가슴살의 활용도를 확대하기 위해 기호도를 높이고, 기능성 소재나 조미 혹은 스 포츠음료로 사용하기 위한 기초자료를 제공하고자 하였다. 종계와 육계 가슴살의 일반성분을 분석한 결과, 수분 함량과 회분함량은 유의적인 차이를 보이지 않았지만, 조지방, 조단 백질, 회분 함량은 유의적인 차이를 보였다. 조지방과 조단백 질의 함량은 육계가 종계보다 높은 함량을 나타내었다 $(1.54$ $\mathrm{g} / 100 \mathrm{~g}, 25.41 \mathrm{~g} / 100 \mathrm{~g})$. 종계 및 육계의 가슴살을 단백질분해 효소로 가수분해한 분해물의 아미노산 특성을 분석한 결과 각 각의 닭가슴살 아미노산은 총 28 종이 검출되었으며, aspartic $\operatorname{acid}(6.88,9.84 \%)$ 가 가장 높은 함량을 나타내었고, 그 다음은 leucine $(2.01,2.99 \%)$, arginine $(0.97,1.32 \%)$ 의 순이었다. 필수 아미노산 중 valine, methionine, isoleucine, leucine, phenylalanine의 함량은 종계에 비해 육계가 높은 함량을 나타내었 다. 필수아미노산 함량은 종계 $5.87 \%$, 육계 $8.29 \%$ 로 유의적 인 차이를 보였으며, 근육형성에 영향을 미치는 분지아미노 산의 함량도 종계 $2.97 \%$, 육계 $4.60 \%$ 로 차이가 있었다. 이 결과로 닭가슴살을 아미노산 보강소재와 조미 혹은 기능성소 재로 사용 가능성이 있음을 확인하였다.

\section{감사의 글}

이 연구에 사용한 닭고기 원료를 제공한 교촌 에프엔비 (주)에 감사를 드립니다.

\section{Conflict of interests}

The authors declare no potential conflict of interest. 


\section{ORCID}

SeungWha Jo https://orcid.org/0000-0002-1114-868X

DongHwa Shin https://orcid.org/0000-0002-3745-6955

\section{References}

Ahn DH, Park SY. Studies on components related to taste such as free amino acids and nucleotides in Korean native chicken meat. J Korean Soc Food Sci Nutr, 31, 547-552 (2002)

Bae JY, Koo GH, Park SC, Shin KO. Effects of branchedchain amino acid and glutamine supplementation on angiogenic factors and pro-inflammatory cytokines after acute exercise in adolescence athletes. Asian J Kinesiol, 21, 51-58 (2019)

Chae HS, Choi HC, Na JC, Kim MJ, Kang HK, Kim DW, Kim JH, Jo SH, Kang GH, Seo OS. Effect of raising periods on amino acids and fatty acids properties of chicken meat. Korean J Poult Sci, 39, 77-85 (2012)

Chen Y, Qiao Y, Xiao Y, Chen H, Zhao L, Huang M, Zhou G. Differences in physicochemical and nutritional properties of breast and thigh meat from crossbred chickens, commercial broilers, and spent hens. Asian Australas J Anim Sci, 29, 855-864 (2016)

Felig P. The glucose-alanine cycle. Metabolism, 22, 179-207 (1973)

Foure A, Bendahan D. Is branched-chain amino acids supplementation an efficient nutritional strategy to alleviate skeletal muscle damage? A systematic review. Nutrients, 9, 1047 (2017)

Hasegawa S, Ichiyama T, Sonaka I, Ohsaki A, Okada S, Wakiguchi H, Kudo K, Kittaka S, Hara M, Furukawa S. Cysteine, histidine and glycine exhibit anti-inflammatory effects in human coronary arterial endothelial cells. Clin Exp Immunol, 167, 269-274 (2012)

Hong JS, Kim YH, Kim MK, Kim YS, Sohn HS. Contents of free amino acids and total amino acids in Agaricus bisporus, Pleurotus ostreatus and Lentinus edodes. Korean J Food Sci Technol, 28, 58-62 (1989)

Jung MO, Choi JS, Lee JH, Lee HJ, Kang M, Choi YI. Quality characteristics of breast meats among broiler, Korean native chicken and old layer. Bulletin Ani Biotech, 5, 69-73 (2013)
Kalogeropoulou D, LaFave L, Schweim K, Gannon MC, Nuttall FQ. Leucine, when ingested with glucose, synergistically stimulates insulin secretion and lowers blood glucose. Metabolism, 57, 1747-1752 (2008)

KDCA. Korea Health Statistics. Korea National Health and Nutrition Examination Survey, Sejong, Korea, p 2-27 (2019)

Kim MJ. Nutritional value and characteristics of different part in chicken meat. Monthly Korean Chicken, 17, 90-93 (2011)

Kim SJ, Choi WS, You SG, Min YS. Effect of glucomannan on quality and shelf-life of low-fat chicken patty. Korean J Food Sci Technol, 39, 55-60 (2007)

Koh HY, Yu IJ. Nutritional analysis of chicken parts. J Korean Soc Food Sci Nutr, 44, $1028-1034$ (2015)

Kong F, Tang J, Lin M, Rasco B. Thermal effects on chicken and salmon muscles: Tenderness, cook loss, area shrinkage, collagen solubility and microstructure. LWT-Food Sci Technol, 41, 1210-1222 (2008)

Kwon JH, Byun MW, Cho HO, Kim YJ, Kim JG. Effect of chemical fumigant and $\gamma$-rays on the physicochemical properties of dried oak mushrooms. Korean J Food Sci Technol, 19, 273-278 (1987)

Lee YS, Saha A, Xiong R, Owens CM, Meullenet JF. Changes in broiler breast fillet tenderness, water-holding capacity, and color attributes during long-term frozen storage. J Food Sci, 73, 162-168 (2008)

MAFRA. Agriculture, Food and Rural Affairs Statistics Yearbook. Ministry of Agriculture Food and Rural Affairs, Sejong, Korea, p 380-381 (2018)

Nam KC. The age of chicken breed recognition. Koran Society Food Sci Ani Resour, 8, 48-54 (2019)

Patel K. Branched-chain amino acids. http://examine.com/ supplements/branched-chain-amino-acids. (assessed December 2020)

Postati LP. Composition of Foods. Poultry Products: Raw, Processed, Prepared. USDA, Agriculture Handbook 8-5, Washington DC, USA, p 330 (1979)

Rahimi MH, Shab-Bidar S, Mollahosseini M, Djafarian K. Branched-chain amino acid supplementation and exerciseinduced muscle damage in exercise recovery: A metaanalysis of randomized clinical trials. Nutrition, 42, 30-36 (2017)

RDA. Korean Food Composition Table (9th Revision). Rural 
Development Adminstration, Jeonju, Korea, p 250-251 (2016)

RDA. Tables of Five Functional Composition Amino Acid.

Rural Development Adminstration, Jeonju, Korea, $p$ 76-77 (2011)

RRDI. Rural Resources Development Institute. Nutritional Composition of Meat Each Part, Suwon, Korea, p 81 (2007)

Schilling MA, Vidal P, Ployhart RE, Marangoni A. Learning by doing something else: Variation, relatedness, and the learning curve. Manage Sci, 49, 39-56 (2003)

Scott ML. Composition of turkey meat. J Am Diet Assoc, 32, 941-944 (1956)

Simpson MD, Goodwin TL. Chemical composition and yield of cornish game hens and broilers. Poult Sci, 58, 1400-1402 (1979)

Singh SP, Essary EO. Influence of thawing methods on the composition of drip from broiler carcasses. Poult Sci, 50, 364-369 (1971)

Temesgen M. RettA N, Tesfaye E. Chicken amino acid and fatty acid: Effect of feeding Taro leaf in the diet. Acta Sci Nutr Health, 2, 12-18 (2018)
Thielke S, Lhafi SK, Kyhne M. Effects of aging prior to freezing on poultry meat tenderness. Poult Sci, 84, 607-612 (2005)

Twining PV Jr, Thomas OP, Bossard EH. Effect of diet and type of birds on the carcass composition of broiler at 28 , 49, and 59 days of age. Poult Sci, 57, $492-497$ (1978) Tymoczko JL, Berg JM, Stryer L. Biochemistry: A Short Course 2nd ed, W H Freeman and company, USA Gordonsvill, VA, p 35-42 (2011)

USDA. Dietary Guidelines for Americans 2015-2020. 8th ed, US Department of Agriculture, Washington DC, USA, p 97 (2015)

Warkup CC. Improving meat quality: The blueprint approach. BSAP Occas Publ, 17, 63-67 (1993)

Watanabe A, Ueda Y, Higuchi M. Effects of slaughter age on the levels of free amino acids and dipeptides in fattening cattle. Anim Sci J, 75, 361-367 (2004)

Wu G, Morris Jr SM. Arginine metabolism: Nitric oxide and beyond. Biochem J, 336, 1-17 (1998)

Zhao GP, Cui HX, Liu RR, Zheng MQ, Chen JL, Wen J. Comparison of breast muscle meat quality in 2 broiler breeds. Poult Sci, 90, 2355-2359 (2011) 